\title{
AN ANALYSIS OF THE ENVIRONMENTAL PRESSURE EXERTED BY THE EUCALYPTUS-BASED KRAFT PULP INDUSTRY IN THAILAND
}

\author{
WARIT JAWJIT ${ }^{1,2}$, CAROLIEN KROEZE ${ }^{1, *}$, WIT SOONTARANUN ${ }^{3}$ \\ and LEEN HORDIJK ${ }^{4}$ \\ ${ }^{1}$ Environmental Systems Analysis Group, Wageningen University, P.O. Box 8080, 6700 DD, Wageningen, \\ The Netherlands \\ ${ }^{2}$ National Research Center for Environmental and Hazardous Waste Management, Chulalongkorn University, \\ 10330, Bangkok, Thailand \\ ${ }^{3}$ Department of Chemical Engineering, Faculty of Engineering, Chulalongkorn University, 10330, Bangkok, \\ Thailand \\ ${ }^{4}$ International Institute for Applied Systems Analysis (IIASA), A-2361, Laxenburg, Austria \\ (*author for correspondence, e-mail: Carolien.kroeze@wur.nl; \\ fax: +31-317-484839; tel.: +31-317-484812)
}

\begin{abstract}
The study reported here focuses on the environmental pressure exerted by large-scale eucalyptus-based kraft pulp industry in Thailand. The objective of this study was to identify the most important sources of greenhouse gases, acidifying and eutrophying compounds and tropospheric ozone precursors, human toxicity compounds and solid waste associated with the kraft pulp industry. To this end, we performed an environmental systems analysis of the kraft pulp industry system in which we distinguished between two subsystems: the eucalyptus forestry subsystem and the kraft pulp production subsystem. The results indicate that the environmental pressure is caused by the kraft pulp production subsystem rather than by the eucalyptus forestry one. The chemical recovery unit was found to be the most important source of carbon dioxide $\left(\mathrm{CO}_{2}\right)$ and sulfur dioxide $\left(\mathrm{SO}_{2}\right)$ and responsible for more than one-half of the emissions of greenhouse gases and acidifying compounds from eucalyptus-based kraft pulp production in Thailand. Biomass combustion in the energy gene ration unit is an important source of nitrogen oxide $\left(\mathrm{NO}_{x}\right)$ and carbon monoxide $(\mathrm{CO})$ which in turn are responsible for over $50 \%$ of the emissions of tropospheric ozone precursors. About $73 \%$ of the eutrophication is caused by biological aerobic wastewater treatment emitting phosphorus $(\mathrm{P})$. With respect to the eucalyptus forestry, only fertilizer use in eucalyptus plantations is a relevant source of pollution through the emission of nitrous oxide $\left(\mathrm{N}_{2} \mathrm{O}\right)$ and phosphate $\left(\mathrm{PO}_{4}^{3-}\right)$.
\end{abstract}

Key words: environmental systems analysis, eucalyptus forestry, kraft pulp, Thailand.

Abbreviations: AOX: - Absorbable organic halide; AP: - Acidification potential; $\mathrm{CH}_{4}$ : - Methane; $\mathrm{CO}:-$ Carbon monoxide; $\mathrm{CO}_{2}$ : - Carbon dioxide; COD: - Chemical oxygen demand; ECF: - Elemental chlorine free; GWP: - Global warming potentials; LCA: - Life cycle analysis; $\mathrm{N}_{2} \mathrm{O}$ : - Nitrous oxide; $\mathrm{NO}_{x}$ : Nitrogen oxide; NP: - Nutrient potential; POCPs: - Photochemical ozone creation potentials; SIMAPRO: - System for integrated environmental assessment of products; $\mathrm{SO}_{2}$ : - Sulfur dioxide; TRS: - Total reduced sulfur; VOC: - Volatile organic compound.

Readers should send their comments on this paper to: BhaskarNath@aol.com within 3 months of publication of this issue. 


\section{W. JAWJIT ET AL.}

\section{Introduction}

The pulp industry is one of the important fundamental industries in Thailand. With an average annual growth of $5 \%$ (DIW, 1999), the production capacity is increasing steadily, and new expansion projects are currently underway. A consequence of this growth is an increasing concern about the environmental impacts. However, to date, there have been no integrated studies that analyze the environmental impact of kraft pulp production in Thailand. One possibility is to carry out an environmental systems analysis. Several environmental systems analysis tools exist that could be useful in this respect and which also help to evaluate the reduction options. One of the analytical tools often used in systems analysis is life cycle analysis (LCA). This approach considers the impacts associated with individual products, taking into account the entire life cycle ranging from raw material acquisition, manufacture, transportation and product use and discard. In Thailand, the majority of the pulp is produced in a eucalyptus-based kraft process (ERIC and TPPIA, 2002). Therefore, a study of the environmental performance of pulp production also needs to take the eucalyptus plantation system into account.

To date, only a few studies on the environmental performance of pulp production in Thailand have been carried out. Ongmongkolkul and Nielsen (2001) included a pulp production component in a study of LCA of paperboard packaging in Thailand. Because of the scarcity of information available on the pulp and paper industry in Thailand, these investigators used the System for Integrated Environmental Assessment of Products (SIMAPRO) as a calculation tool. Their study included a first estimate of the environmental impact of the eucalyptus forestry using data obtained from the Danish wood industry. A recent study by the Thailand Environmental Institute (TEI, 1999) on the industrial environmental index indicated that there were indeed difficulties in obtaining information from the pulp and paper industry for a number of indicators, such as AOX (adsorbable organic halides), TRS (total reduced sulfur) and VOC (volatile organic compounds). Consequently, studies aimed at obtaining more site-specific information are necessary in order to achieve a more accurate and reliable data on the environmental impact of the pulp and paper industry in Thailand. The use of databases from other sources or software, which are not Thailand-based, may not best represent the state of the pulp industry in Thailand. To improve our understanding of the environmental performance of pulp production in Thailand, analyses need to be performed on information obtained locally.

In the study reported here, we focused on the pressure exerted by eucalyptus-based kraft pulp production on the environment in Thailand. When analyzing the emission of pollutants related to the agricultural and industrial sector, one may aim for a full LCA approach of all products. However, with respect to pulp and paper production in Thailand, this is not feasible because of the complexity of the industry. It would be much too time-consuming because of the large number of final products of paper, each having their own unique production process. Therefore, we decided not to perform a full LCA; instead, we focused on eucalyptus kraft pulp as a final product. 


\section{KRAFT PULP INDUSTRY IN THAILAND}

Another problem is to determine which parts of the production chain have to be described in order to be able to analyze environmental problems related to eucalyptus plantation and kraft pulp production - without performing a full LCA for all of the products involved. In the other words: what are the system boundaries and how can we decide which inputs, outputs and processes have to be taken into account and which can be omitted? The aim of this study was to contribute to an answer to these questions by analyzing the current environmental pressure exerted by the pulp production in Thailand. This can be done by making an inventory of the sources of greenhouse gases, of acidifying and eutrophying compounds as well as of tropospheric ozone precursors, human toxicity substances and solid wastes from the eucalyptus-based kraft pulp industry in Thailand.

Based on this inventory, our primary aim was to identify the most important sources of the different pollutants. Following the LCA philosophy, we focused not only on pulp production but also on the eucalyptus forestry sector producing the raw material for kraft pulp production. A second aim of our analysis was to reveal which emissions need to be taken into account in a systems analysis aiming at analyzing possible reduction strategies. The analysis reported here was based, as much as possible, on information obtained locally.

\section{Methodology}

The first step of environmental systems analysis methodology - problem definition was used in this study. Problem definition includes a clear definition of the system by listing the system inputs, outputs and their relations, and analyzes which inputs, outputs and processes have to be taken into account and which can be omitted (Pluimers, 2001). In this section the system definition is described in detail. The main sources of pollutants, derived from commercial activities in the eucalyptus-based kraft pulp industry, are identified. The method for calculating the emission and environmental impacts are also presented together with the sources of the information.

\subsection{System Definition}

The definition of system boundaries depends partly on the focus and purpose of the study. In this study the system of the eucalyptus-based kraft pulp industry in Thailand consists of two subsystems - the eucalyptus forestry subsystem and kraft pulp production (Figure 1). The study was restricted to these two subsystems because the purpose of this study was to identify potential contributors to emissions from the eucalyptus forestry and kraft pulp industry which would then be used for determining potential reduction options during subsequent investigations at the level of these two subsystems.

The eucalyptus forestry (only for the purpose of pulp-making) subsystem in Thailand includes four important sources of pollutants: eucalyptus breeding, eucalyptus 
W. JAWJIT ET AL.

Production chain

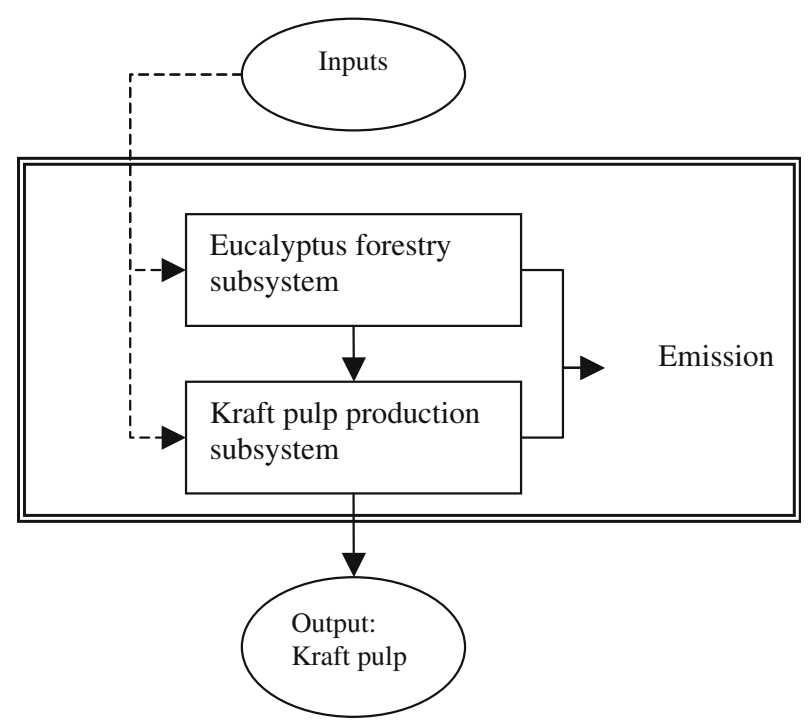

Figure 1. Schematic overview of the kraft pulp industry system in Thailand, including two subsystems: the eucalyptus forestry and the kraft pulp production. The double line indicates the system boundary.

plantation, harvesting and transportation. A schematic overview of the eucalyptus forestry subsystem and its environmental impact is shown in Figure 2. Eucalyptus is selected in this study because it supplies the largest proportion $(>80 \%)$ of raw material for pulp production in Thailand (DIW, 1999) and has progressively taken over the share of other raw materials such as bamboo, bagasses and kenaf. Eucalyptus has such a dominant role because it is fast-growing and its quality can easily be controlled to suit

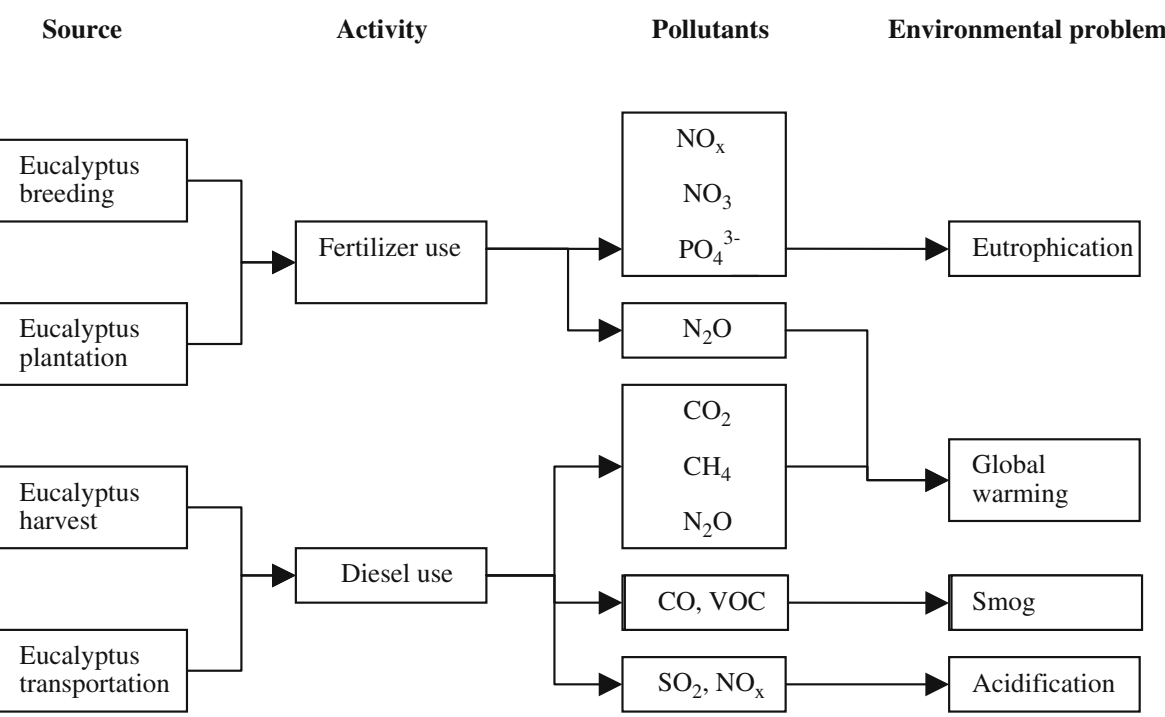

Figure 2. A schematic overview of the eucalyptus forestry subsystem and its environmental impacts. 


\section{KRAFT PULP INDUSTRY IN THAILAND}

the pulp production. Although there have been some concerns expressed on the ecological effects of the eucalyptus plantation subsystem, such as soil impoverishment, this aspect was not included in the present study. Time limitation was the main obstacle because a study of ecological effect requires at least 4 years, which is the common number of rotation years for eucalyptus plantations in Thailand. Also, this study focused on the emission of pollutants rather than on natural resource deterioration.

The emissions from four important sources (units) of pollutants are included in the kraft pulp production subsystem in Thailand: the pulp production unit (raw material preparation, pulp digesting, pulp washing, pulp bleaching and sheet forming), chemical recovery unit, energy generation unit and wastewater treatment unit. In kraft pulp mills in Thailand, elemental chlorine free (ECF) is used in pulp bleaching, whereas the biomass (eucalyptus bark as a major source) co-generation system is used for energy (heat and electricity) generation. Activated sludge is favorite wastewater treatment process used in pulp mills in Thailand (TEI, 1997; DIW, 1999; ERIC and TPPIA, 2002). Administrative activities such as electricity use, water use and waste generation from toilets and canteens were not included. A schematic overview of kraft pulp production and its environmental impact is shown in Figure 3. The pulp production process in this study included only the kraft process for three reasons. First, in Thailand the kraft process is more widely applied than other processes using eucalyptus as a raw material; it also has a larger phase (about $80 \%$ ) in eucalyptus pulp production than other pulp production processes (DIW, 1999). Second, this process is the most versatile process compared with the others and also produces the strongest pulp (UNEP, 1996). Third, good-quality data for the kraft process are readily available.

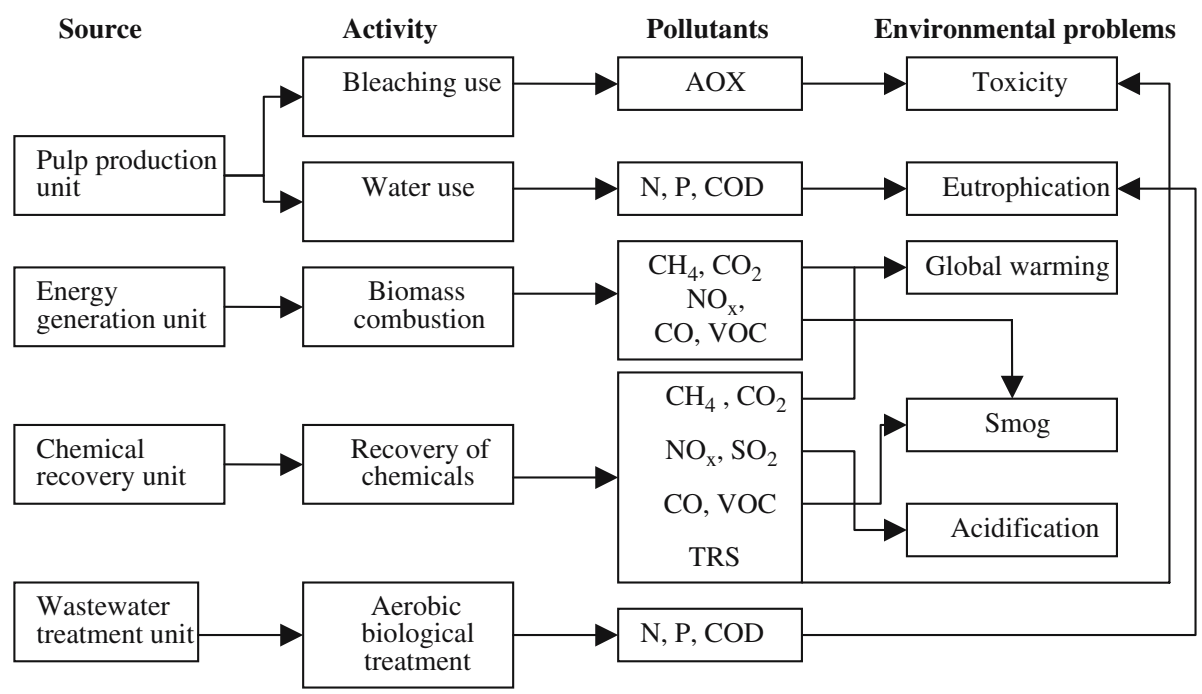

Figure 3. A schematic overview of the kraft pulp production subsystem and its environmental impacts. 


\section{W. JAWJIT ET AL.}

\subsection{Calculation of Emissions and Environmental Impacts}

In this study we took into account six environmental impacts: global warming, acidification, eutrophication, smog, human toxicity and the production of waste. The emissions related to these impacts include $\mathrm{CO}_{2}, \mathrm{CH}_{4}$ and $\mathrm{N}_{2} \mathrm{O}$ (global warming), $\mathrm{SO}_{2}$ and $\mathrm{NO}_{x}$ (acidification), $\mathrm{COD}, \mathrm{PO}_{4}{ }^{3-}, \mathrm{NO}_{3}{ }^{-}$, total $\mathrm{N}$ and total $\mathrm{P}$ (eutrophication), non-methane (NM)VOCs, $\mathrm{CO}, \mathrm{CH}_{4}$, and $\mathrm{NO}_{x}$ (smog) and particulates, AOX, TRS, $\mathrm{SO}_{2}$ and $\mathrm{NO}_{x}$ (human toxicity). Only data on the production of waste was directly acquired from mills' reports; other emissions wee calculated as a function of agricultural and industrial activities (shown in Tables I and II) and the emission factors (shown in Table III) using the following equation:

$$
\text { EMISSION }=\text { ACTIVITY } \times \text { EMISSION FACTOR }
$$

Activities in the eucalyptus forestry subsystem that contribute to the emissions include the use of diesel in harvesting, the transportation of timber to pulp mills and fertilizer use in tree breeding and plantation. The use of diesel in eucalyptus hauling is omitted because man-work is more favorable in Thailand than the use of machinery. Activity data for the calculation of emissions originating from activities associated with the eucalyptus plantation subsystem in Thailand are shown in Table I.

Activities in the kraft pulp production subsystem include biomass combustion, the use of bleaching agents, bunker oil use, lime burning and biological wastewater treatment. When we were unable to quantify the activities which generate pollutants, we calculated the emission using the emission factor related to the production capacity. In this context, the production capacity can be virtually thought of as an activity. In 2001, which we used as our basis for all calculations, 612,000 ton of kraft pulp was produced (ERIC and TPPIA, 2002). Table II shows the activity data for the calculation of emissions from the kraft pulp production subsytem in Thailand. The results of the emission calculations are expressed in tons of pollutants either emitted or generated from the kraft pulp industry system in Thailand per year (ton/ year).

The activity data and emission factors that were used to quantify the emissions are considered to be the best data available to date. We first used the activity data and emission factors that were already available on forestry and pulp production in

TABLE I. Activity data for the calculation of emissions from eucalyptus forestry in Thailand (as used in Eq. 1).

\begin{tabular}{|c|c|c|c|c|}
\hline Source & Activity & Value & Unit & Reference \\
\hline Eucalyptus & N-fertilizer use & 2.46 & ton/year & Estimated from Cherdkietkul ( personal com- \\
\hline breeding & P-fertilizer use & 1.15 & ton/year & munication) \\
\hline Eucalyptus & N-fertilizer use & 1054 & ton/year & All estimated from Poethai (1997) \\
\hline plantation & P-fertilizer use & 1054 & ton/year & $\begin{array}{l}\text { Hoamuangkaew et al. (1999) and Cher- } \\
\text { dkietkul (personal communication) }\end{array}$ \\
\hline $\begin{array}{l}\text { Eucalyptus } \\
\text { harvest }\end{array}$ & Diesel use & 695,111 & $\mathrm{~kg}$ fuel/year & $\begin{array}{l}\text { All estimated from Poethai (1997) and Sch- } \\
\text { waiger and Zimmer (1995) }\end{array}$ \\
\hline $\begin{array}{l}\text { Eucalyptus } \\
\text { transportation }\end{array}$ & Diesel use & $2,040,000$ & $\mathrm{~kg}$ fuel/year & \\
\hline
\end{tabular}




\section{KRAFT PULP INDUSTRY IN THAILAND}

TABLE II. Activity data for the calculation of emissions from kraft pulp production in Thailand (as used in Eq. 1).

\begin{tabular}{|c|c|c|c|c|}
\hline Source & Activity & Value & Unit & Reference \\
\hline Pulp bleaching unit & $\begin{array}{l}\text { Bleaching } \\
\text { agent use }\end{array}$ & 6,432 & Ton/year & DIW (1999) \\
\hline $\begin{array}{l}\text { Chemical } \\
\text { recovery unit }\end{array}$ & Lime burning & $1,970,878$ & Ton/year & DIW (1999) \\
\hline $\begin{array}{l}\text { Chemical } \\
\text { recovery unit }\end{array}$ & $\begin{array}{l}\text { Bunker } \\
\text { oil use }\end{array}$ & 916 & $\mathrm{TJ} /$ year & $\begin{array}{l}\text { DIW (1999), estimated } \\
\text { from IPCC (1997) }\end{array}$ \\
\hline $\begin{array}{l}\text { Energy } \\
\text { production unit }\end{array}$ & $\begin{array}{l}\text { Biomass } \\
\text { combustion }\end{array}$ & 17,258 & $\mathrm{TJ} /$ year & ERIC and TPPIA (2002) \\
\hline $\begin{array}{l}\text { Wastewater } \\
\text { treatment unit }\end{array}$ & $\begin{array}{l}\text { Biological } \\
\text { treatment }\end{array}$ & $17,870,400$ & $\mathrm{~m}^{3} /$ year & ERIC and TPPIA (2002) \\
\hline
\end{tabular}

Thailand. However, some values, such as emission factors in the chemical recovery unit, were not available or well processed. These values, therefore, were obtained from sources which are commonly used and widely accepted, such as emission factors described by the IPCC (1997) and CORINAIR (2000). Moreover, some data could not be obtained directly from a single source, and in these cases we used integrated information from multiple sources to estimate such data (for example, fertilizer use in eucalyptus forestry). Some simplifying assumptions with respect to the calculations also needed to be made. For instance, the average distance between plantation site and pulp production factory was taken to be $100 \mathrm{~km}$, but in reality the distance may vary from 4 to $200 \mathrm{~km}$. In the kraft pulp mill subsystem, biomassbased fuel (eucalyptus bark) was assumed to be the only fuel used for combustion in the boiler because it is by far the major total fuel source (about 90\%) (ERIC and TPPIA, 2002), although some dried sludge is also used as additional fuel.

The integrated environmental impact of the emissions wa calculated using classification factor (shown in Table IV) as follows (Heijungs et al., 1992):

$$
\text { IMPACT }=\text { EMISSION } \times \text { CLASSIFICATION FACTOR }
$$

In th present analysis, classification factors based on six different environmental themes namely global warming, acidification, eutrophication, smog, human toxicity and production of waste, were used.

\section{Global warming}

Greenhouse gases, which are the main pollutants contributing to global warming problem, are expressed as GWP (global warming potentials). The GWP is an index of cumulative radiative forcing between the present and some chosen later time horizon caused by a unit mass of gas emitted, expressed relative to the reference gas $\mathrm{CO}_{2}(1 \mathrm{~kg} \mathrm{CO})$ (Houghton 1994). The combustion of fuels in the pulp mill is the major source of these gases.

In the case of forestry, the growth of eucalyptus acts as a $\mathrm{CO}_{2}$ sink through photosynthesis. The calculation of $\mathrm{CO}_{2}$ sequestration, therefore, can be taken into account by following the IPCC (1997) procedure: 


\section{W. JAWJIT ET AL.}

TABLE III. Emission factors as used in Eq. 1 for the calculation of the emissions from eucalyptus forestry and kraft pulp production.

\begin{tabular}{|c|c|c|c|}
\hline Compound emitted & Emission factor & Unit & Reference \\
\hline \multicolumn{4}{|l|}{ Eucalyptus forestry } \\
\hline \multicolumn{4}{|l|}{ Fertilizer use } \\
\hline \multicolumn{4}{|l|}{$\mathrm{N}$ fertilizer use } \\
\hline $\mathrm{N}_{2} \mathrm{O}$ & 0.03 & $\mathrm{~kg} \mathrm{~N}_{2} \mathrm{O}-\mathrm{N} / \mathrm{kg} \mathrm{N}$ & IPCC (1997) \\
\hline $\mathrm{NO}_{x}$ & 0.025 & $\mathrm{~kg} \mathrm{NO}_{x}-\mathrm{N} / \mathrm{kg} \mathrm{N}$ & IPCC (1997) \\
\hline $\mathrm{NO}_{3}^{-}$ & 0.35 & $\mathrm{~kg} \mathrm{NO}_{3}-\mathrm{N} / \mathrm{kg} \mathrm{N}$ & IPCC (1997) \\
\hline \multicolumn{4}{|l|}{ P fertilizer use } \\
\hline $\mathrm{PO}_{4}^{3-}$ & 0.2 & $\mathrm{~kg} \mathrm{PO}_{4}-\mathrm{P} / \mathrm{kg} \mathrm{P}$ & IPCC (1997) \\
\hline \multirow{2}{*}{\multicolumn{4}{|c|}{$\begin{array}{l}\text { Diesel use in forestry } \\
\text { operation } \\
\text { Harvest }\end{array}$}} \\
\hline Harvest & & & \\
\hline $\mathrm{CO}_{2}$ & 3150 & $\mathrm{~g} / \mathrm{kg}$ fuel & Schwaiger and Zimmer (1995) \\
\hline $\mathrm{N}_{2} \mathrm{O}$ & 0.02 & $\mathrm{~g} / \mathrm{kg}$ fuel & Schwaiger and Zimmer (1995) \\
\hline $\mathrm{CH}_{4}$ & 6.91 & $\mathrm{~g} / \mathrm{kg}$ fuel & Schwaiger and Zimmer (1995) \\
\hline $\mathrm{NO}_{x}$ & 50 & $\mathrm{~g} / \mathrm{kg}$ fuel & IPCC (1997) \\
\hline NMVOC & 6.5 & $\mathrm{~g} / \mathrm{kg}$ fuel & IPCC (1997) \\
\hline $\mathrm{CO}$ & 15 & $\mathrm{~g} / \mathrm{kg}$ fuel & IPCC (1997) \\
\hline \multicolumn{4}{|l|}{ Transportation } \\
\hline $\mathrm{CO}_{2}$ & 3180 & $\mathrm{~g} / \mathrm{kg}$ fuel & Schwaiger and Zimmer (1995) \\
\hline $\mathrm{N}_{2} \mathrm{O}$ & 0.1 & $\mathrm{~g} / \mathrm{kg}$ fuel & Schwaiger and Zimmer (1995) \\
\hline $\mathrm{CH}_{4}$ & 0.2 & $\mathrm{~g} / \mathrm{kg}$ fuel & Schwaiger and Zimmer (1995) \\
\hline $\mathrm{NO}_{x}$ & 29.8 & $\mathrm{~g} / \mathrm{kg}$ fuel & IPCC (1997) \\
\hline NMVOC & 4.7 & $\mathrm{~g} / \mathrm{kg}$ fuel & IPCC (1997) \\
\hline $\mathrm{CO}$ & 14 & $\mathrm{~g} / \mathrm{kg}$ fuel & IPCC (1997) \\
\hline $\mathrm{SO}_{2}$ & 20 & $\mathrm{~g} / \mathrm{kg}$ fuel & IPCC (1997), PCD (1996) \\
\hline \multicolumn{4}{|l|}{ Pulp production unit } \\
\hline \multicolumn{4}{|l|}{ Wood handling } \\
\hline $\mathrm{COD}$ & 3 & $\mathrm{~kg} /$ ton dried pulp & EC (2001) \\
\hline \multicolumn{4}{|l|}{ Pulp cooking } \\
\hline TRS & 2.5 & $\mathrm{~kg} /$ ton dried pulp & EC (2001) \\
\hline NMVOC & 0.1 & $\mathrm{~kg} /$ ton dried pulp & EC (2001) \\
\hline \multicolumn{4}{|l|}{ Pulp washing } \\
\hline COD & 6 & $\mathrm{~kg} /$ ton dried pulp & EC (2001) \\
\hline NMVOC & 0.27 & $\mathrm{~kg} /$ ton dried pulp & CORINAIR (2000) \\
\hline \multicolumn{4}{|l|}{ Pulp bleaching } \\
\hline COD & 11 & $\mathrm{~kg} /$ ton dried pulp & EC (2001) \\
\hline $\mathrm{N}$ & 0.19 & $\mathrm{~kg} /$ ton dried pulp & DIW (1999) \\
\hline AOX & 0.1 & $\mathrm{~kg} / \mathrm{kg}$ bleaching use & EPA (1993) \\
\hline NMVOC & 0.05 & $\mathrm{~kg} /$ ton dried pulp & EC (2001) \\
\hline \multicolumn{4}{|c|}{$\begin{array}{l}\text { Energy generation unit } \\
\text { Fuel combustion } \\
\text { (biomass combustion) }\end{array}$} \\
\hline $\mathrm{CO}_{2}$ & 110 & ton/TJ & IPCC (1997) \\
\hline $\mathrm{CH}_{4}$ & 30 & $\mathrm{~kg} / \mathrm{TJ}$ & IPCC (1997) \\
\hline $\mathrm{N}_{2} \mathrm{O}$ & 4 & $\mathrm{~kg} / \mathrm{TJ}$ & IPCC (1997) \\
\hline NMVOC & 50 & $\mathrm{~kg} / \mathrm{TJ}$ & IPCC (1997) \\
\hline $\mathrm{CO}$ & 4000 & $\mathrm{~kg} / \mathrm{TJ}$ & IPCC (1997) \\
\hline $\mathrm{NO}_{x}$ & 100 & $\mathrm{~kg} / \mathrm{TJ}$ & IPCC (1997) \\
\hline Particulates & 1 & $\mathrm{~kg} /$ ton dried pulp & EC (2001) \\
\hline \multicolumn{4}{|c|}{ Chemical recovery unit } \\
\hline \multicolumn{4}{|l|}{ Evaporation tank } \\
\hline NMVOC & 0.05 & $\mathrm{~kg} /$ ton dried pulp & EC (2001) \\
\hline TRS & 0.001 & $\mathrm{~kg} /$ ton dried pulp & Bordado and Gomes (2003) \\
\hline
\end{tabular}




\section{KRAFT PULP INDUSTRY IN THAILAND}

TABLE III. Continued.

\begin{tabular}{|c|c|c|c|}
\hline Compound emitted & Emission factor & Unit & Reference \\
\hline \multicolumn{4}{|l|}{ Recovery boiler } \\
\hline $\mathrm{CO}_{2}$ & 6 & $\mathrm{~kg} /$ ton dried pulp & TEI (1997), DIW (1999) \\
\hline $\mathrm{SO}_{2}$ & 0.2 & $\mathrm{~kg} /$ ton dried pulp & Poyry (1992), Bordado and Gomes (2003) \\
\hline $\mathrm{NO}_{x}$ & 1.03 & $\mathrm{~kg} /$ ton dried pulp & Poyry (1992), CORINAIR (2000) \\
\hline $\mathrm{CO}$ & 5.5 & $\mathrm{~kg} /$ ton dried pulp & CORINAIR (2000) \\
\hline NMVOC & 0.332 & $\mathrm{~kg} /$ ton dried pulp & CORINAIR (2000) \\
\hline TRS & 0.003 & $\mathrm{~kg} /$ ton dried pulp & Bordado and Gomes (2003) \\
\hline Particulates & 1.2 & $\mathrm{~kg} /$ ton dried pulp & Poyry (1992), Bordado and Gomes (2003) \\
\hline \multicolumn{4}{|l|}{ Smelt tank } \\
\hline $\mathrm{SO}_{2}$ & 0.03 & $\mathrm{~kg} /$ ton dried pulp & Bordado and Gomes (2003) \\
\hline $\mathrm{NO}_{x}$ & 0.01 & $\mathrm{~kg} /$ ton dried pulp & Bordado and Gomes (2003) \\
\hline TRS & 0.009 & $\mathrm{~kg} /$ ton dried pulp & Bordado and Gomes (2003) \\
\hline Particulates & 0.1 & $\mathrm{~kg} /$ ton dried pulp & Bordado and Gomes (2003) \\
\hline \multicolumn{4}{|l|}{ Lime combustion } \\
\hline $\mathrm{CO}_{2}$ & 0.44 & ton/ton-lime mud & ERIC and TPPIA (2002) \\
\hline $\mathrm{SO}_{2}$ & 0.55 & $\mathrm{~kg} /$ ton dried pulp & Poyry (1992), Bordado and Gomes (2003) \\
\hline $\mathrm{NO}_{x}$ & 0.33 & $\mathrm{~kg} /$ ton dried pulp & Poyry (1992), Bordado and Gomes (2003) \\
\hline Particulates & 0.1 & $\mathrm{~kg} / \mathrm{ton}$ dried pulp & Poyry (1992) \\
\hline \multicolumn{4}{|l|}{$\begin{array}{l}\text { Bunker oil use } \\
\text { (in lime kiln) }\end{array}$} \\
\hline $\mathrm{CO}_{2}$ & 77.4 & ton/TJ & IPCC (1997) \\
\hline $\mathrm{CH}_{4}$ & 2 & $\mathrm{~kg} / \mathrm{TJ}$ & IPCC (1997) \\
\hline $\mathrm{N}_{2} \mathrm{O}$ & 0.6 & $\mathrm{~kg} / \mathrm{TJ}$ & IPCC (1997) \\
\hline $\mathrm{SO}_{2}$ & 1194 & $\mathrm{~kg} / \mathrm{TJ}$ & IPCC (1997) \\
\hline $\mathrm{NO}_{x}$ & 200 & $\mathrm{~kg} / \mathrm{TJ}$ & IPCC (1997) \\
\hline $\mathrm{CO}$ & 10 & $\mathrm{~kg} / \mathrm{TJ}$ & IPCC (1997) \\
\hline NMVOC & 5 & $\mathrm{~kg} / \mathrm{TJ}$ & IPCC (1997) \\
\hline \multicolumn{4}{|l|}{$\begin{array}{l}\text { Wastewater treatment } \\
\text { unit }\end{array}$} \\
\hline $\mathrm{CO}_{2}$ & 339.1 & $\mathrm{~g} / \mathrm{m}^{3}$ & CORINAIR (2000) \\
\hline $\mathrm{CH}_{4}$ & 3.7 & $\mathrm{~g} / \mathrm{m}^{3}$ & CORINAIR (2000) \\
\hline $\mathrm{N}_{2} \mathrm{O}$ & 0.25 & $\mathrm{~g} / \mathrm{m}^{3}$ & CORINAIR (2000) \\
\hline $\mathrm{P}$ & 0.84 & $\mathrm{~kg} /$ ton dried pulp & DIW (1999) \\
\hline
\end{tabular}

Total annual biomass $\mathrm{C}$ uptake by eucalyptus

$$
\mathrm{Cs}=\mathrm{AP} \times \mathrm{GP} \times \mathrm{CP}
$$

where $\mathrm{Cs}=$ annual biomass $\mathrm{C}$ uptake (ton $\mathrm{C} /$ year); $\mathrm{AP}=$ area of plantation (ha); $\mathrm{GP}=$ annual biomass growth rate (ton dry matter/ha per year); $\mathrm{CP}=\mathrm{C}$ fraction in plantation or plant species (ton $\mathrm{C} /$ ton dry matter). $\mathrm{CO}_{2}$ sequestration by eucalyptus (ton/year) is then

$$
\mathrm{CO}_{2}=\mathrm{Cs} \times(44 / 12)
$$

However, although both emissions as well as the $\mathrm{CO}_{2}$ capture during eucalyptus growth are quantified, the net effect of the two will not be quantified. The net greenhouse gas flux cannot be quantified because $\mathrm{CO}_{2}$ losses after the produced paper is discarded are not considered. Moreover, this study considered the plantation of eucalyptus as a ,normal forest' system. A normal forest consists of an equal 


\section{W. JAWJIT ET AL.}

TABLE IV. Classification factors used in Eq. 2 for the emissions of greenhouse gases, acidifying gases, eutrophying compounds, tropospheric ozone precursors and human toxicity compounds.

\begin{tabular}{|c|c|c|c|}
\hline Environmental theme & Compounds & Classification factor & Reference \\
\hline \multirow[t]{3}{*}{ Global warming } & $\mathrm{CO}_{2}$ & $1 \mathrm{~kg}=1 \mathrm{CO}_{2}$-eq & IPCC (1997) \\
\hline & $\mathrm{CH}_{4}$ & $1 \mathrm{~kg}=21 \mathrm{CO}_{2}$-eq & \\
\hline & $\mathrm{N}_{2} \mathrm{O}$ & $1 \mathrm{~kg}=310 \mathrm{CO}_{2}$-eq & \\
\hline \multirow[t]{2}{*}{ Acidification } & $\mathrm{SO}_{2}$ & $1 \mathrm{~kg}=1 \mathrm{SO}_{2}$-eq & Heijung et al. (1992) \\
\hline & $\mathrm{NO}_{x}$ & $1 \mathrm{~kg}=0.71 \mathrm{SO}_{2}-\mathrm{eq}$ & \\
\hline \multirow[t]{6}{*}{ Eutrophication } & $\mathrm{NO}_{x}$ & $1 \mathrm{~kg}=0.13 \mathrm{PO}_{4}-\mathrm{eq}$ & Heijung et al. (1992) \\
\hline & $\mathrm{NO}_{3}$ & $1 \mathrm{~kg}=0.1 \mathrm{PO}_{4}$-eq & \\
\hline & $\mathrm{N}$ & $1 \mathrm{~kg}=0.42 \mathrm{PO}_{4}$-eq & \\
\hline & $\mathrm{PO}_{4}$ & $1 \mathrm{~kg}=1 \mathrm{PO}_{4}$-eq & \\
\hline & $\mathrm{P}$ & $1 \mathrm{~kg}=3.06 \mathrm{PO}_{4}$-eq & \\
\hline & COD & $1 \mathrm{~kg}=0.022 \mathrm{PO}_{4}-\mathrm{eq}$ & \\
\hline \multirow[t]{4}{*}{ Smog } & NMVOC & $1 \mathrm{~kg}=0.416$ ethylene-eq & Goedkoop (2000) \\
\hline & $\mathrm{CO}$ & $1 \mathrm{~kg}=0.027$ ethylene-eq & \\
\hline & $\mathrm{CH}_{4}$ & $1 \mathrm{~kg}=0.006$ ethylene-eq & \\
\hline & $\mathrm{NO}_{x}$ & $1 \mathrm{~kg}=0.028$ ethylene-eq & \\
\hline \multirow[t]{5}{*}{ Human toxicity } & $\mathrm{AOX}^{\mathrm{a}}$ & $1 \mathrm{~kg}=1 \mathrm{C}_{6} \mathrm{H}_{4} \mathrm{Cl}_{2}-\mathrm{eq}$ & CML (2002) \\
\hline & $\mathrm{TRS}^{\mathrm{b}}$ & $1 \mathrm{~kg}=0.22 \mathrm{C}_{6} \mathrm{H}_{4} \mathrm{Cl}_{2}$-eq & \\
\hline & $\mathrm{SO}_{2}$ & $1 \mathrm{~kg}=0.096 \mathrm{C}_{6} \mathrm{H}_{4} \mathrm{Cl}_{2}$-eq & \\
\hline & $\mathrm{NO}_{x}$ & $1 \mathrm{~kg}=1.2 \mathrm{C}_{6} \mathrm{H}_{4} \mathrm{Cl}_{2}$-eq & \\
\hline & Particulates & $1 \mathrm{~kg}=0.82 \mathrm{C}_{6} \mathrm{H}_{4} \mathrm{Cl}_{2}$-eq & \\
\hline
\end{tabular}

${ }^{\mathrm{a}}$ Classification factor of dichlorobenzene $\left(\mathrm{C}_{6} \mathrm{H}_{4} \mathrm{Cl}_{2}\right)$ is used for AOX.

${ }^{\mathrm{b}}$ Classification factor of hydrogen sulfide $\left(\mathrm{H}_{2} \mathrm{~S}\right)$ is used for TRS.

area of annual age-classes, with the oldest age-class equal to the chosen rotation age. When the oldest age-class is felled, it will be immediately replanted. In a normal forest, the removal of forest products from the oldest stand exactly counterbalances the growth of those products in all other stands. Thus, there is no change in biomass from year to year and therefore no change in carbon. The whole site is therefore a carbon reservoir, but not a net sink or a net source because the annual growth equals the annual losses (Maclaren, 1996). It should be noted that the current methodology of LCA is not able to deal with the evaluation of the sink-effects of carbon in timber products. The $\mathrm{CO}_{2}$ uptake should, therefore, not be seen as a credit, but as the implementation of the carbon neutrality of wood when its life cycle is taken into consideration (De Feyter, 1995). In the present study, the overall greenhouse gas emission from the eucalyptus-based kraft pulp industry in Thailand is presented and includes $\mathrm{CO}_{2}$ uptake within the eucalyptus-based pulp only for reasons of comparison (Table V).

\section{Acidification}

The kraft pulp production subsystem generates acidifying agents through the production process and chemical recovery since many sulfur-containing chemicals, such as sodium sulfate and sodium sulfide, are used. The combustion of fuel in the pulp mill is the main source of $\mathrm{NO}_{x}$ emissions, although fertilizer use also contributes to the emission of this pollutant. Acidification is measured as the amount of protons released into the terrestrial/aquatic system. The classification factors of acidification 


\section{KRAFT PULP INDUSTRY IN THAILAND}

TABLE V. Input data for the calculation of $\mathrm{CO}_{2}$ sequestration (Eqs. 3 and 4).

\begin{tabular}{|c|c|c|c|c|}
\hline Variable & Description & Value & Unit & Reference \\
\hline AP & Area of plantation & 18,133 & $\mathrm{Ha}$ & Hoamuangkaew et al. (1999) \\
\hline GP & Annual biomass growth rate & 17.4 & ton dry matter/ha per year & TEI (1997) \\
\hline $\mathrm{CP}$ & $\mathrm{C}$ fraction in plant species & 0.5 & ton $\mathrm{C} /$ ton dry matter & IPCC (1997) \\
\hline
\end{tabular}

potential (AP) are routinely presented either as moles of $\mathrm{H}^{+}$or as kilograms of $\mathrm{SO}_{2}$ equivalent (Heijungs et al., 1992). The latter was used in this study.

\section{Eutrophication}

Fertilizer use in the eucalyptus forestry and pulp production unit (cooking, washing and bleaching) at the kraft pulp mill are the most important activities/sources causing the emission of nitrogen and phosphorus. Enrichment of the water and soil with these nutrients may cause an undesirable shift in the composition of species within the ecosystems, a process called eutrophication. Several models have been proposed to characterize the contribution from life-cycle inventory data to eutrophication. One well-known model has been proposed by Heijungs et al. (1992); this model calculates the nutrification potential (NP) of emissions in relation to the one from the reference compound $\mathrm{PO}_{4}{ }^{3-}$.

Smog

The combustion of fuel during the pulp production process and transportation of eucalyptus timber causes the emission of VOCs, $\mathrm{CO}, \mathrm{CH}_{4}$ and $\mathrm{NO}_{x}$, which are considered to be tropospheric ozone precursors. Photochemical ozone creation potentials (POCPs) have been developed to aid in the assessment of the relative contribution of different organic compounds to tropospheric ozone formation. The value of the classification factor of POCPs was taken from Goedkoop (2000) (PReConsultants, Amersfort, the Netherlands) who developed the Eco-indicator 95.

\section{Human toxicity}

In the pulp and paper industry, chlorinated compounds are used as the bleaching agents; consequently, one of the more important water pollutants is AOX, which is considered to be a carcinogenic substance generated during the bleaching process. Another toxic substance included in this study is TRS, which is mainly emitted through the chemical recovery unit. This gas causes a bad odor and can harm the human respiratory system. Because classification factors of AOX and TRS are still not available in LCA methodology, we used classification factors of dichlorobenzene $\left(\mathrm{C}_{6} \mathrm{H}_{4} \mathrm{Cl}_{2}\right)$ for AOX and hydrogen sulfide $\left(\mathrm{H}_{2} \mathrm{~S}\right)$ for TRS. Emissions of particulates, $\mathrm{SO}_{2}, \mathrm{NO}_{x}$ also contribute to human toxicity problem. Classification factors in this environmental theme were taken from CML (2002). 


\section{W. JAWJIT ET AL.}

\section{Production of waste}

The kraft pulp industry generates both organic and inorganic solid wastes. Most of the organic wastes, such as eucalyptus bark and dried sludge, are sent to the boiler to generate heat and electricity in a co-generation system. These organic wastes are then converted to air pollutants. We focused our study of the production of waste on inorganic wastes, such as lime mud, grit and dregs, which, because they cannot be recycled or reused, are used as landfill. The results of waste production are expressed in terms of amount of solid waste per year (ton/year) because there is no available classification factor.

Although all of the data used in the present study to quantify the emissions and environmental impact was considered to be the best data available, the calculated emissions were subject to uncertainty. We did not carry out a sensitivity or uncertainty analysis to analyze the sensitivity of the calculated emissions, including uncertainties in the assumptions and method used. The classification factors used, such as global warming potentials (GWPs) and acidifying and eutrophying potentials also are subject to uncertainties because these values were not developed in Thailand or on Thailand-based data, although GWPs are commonly used and accepted as classification factor for greenhouse gases (IPCC, 1997). The classification factors we used for calculating the $\mathrm{PO}_{4}$-equivalents of eutrophying emissions are less widely used and are based on several assumptions (Heijungs et al., 1992). $\mathrm{PO}_{4}$ equivalents are generally used in LCA studies to indicate the gross effect of eutrophication irrespective of the location of the emissions. However, eutrophication is an environmental problem with typically local effects, and the eutrophication potentials may change when eutrophication is considered as a local problem. Despite these limitations the estimated emission and environmental impact presented here may be the best available at the present time and, therefore, they served the purpose of the study.

\section{Results and discussion}

\subsection{Greenhouse Gases Emission}

Approximately 2.9 Mton $\mathrm{CO}_{2}$-equivalents of greenhouse gas is emitted annually as shown in Table VI. Among the three main components of greenhouse gases $-\mathrm{CO}_{2}$, $\mathrm{CH}_{4}$ and $\mathrm{N}_{2} \mathrm{O}$ - we found that $\mathrm{CO}_{2}$ accounts for almost all of the emissions in terms of both actual and equivalent amounts. When we considered the activities that generate greenhouse gases, biomass combustion in the energy production unit ranks the first, with a share of $65 \%$. The second contributor belongs to lime burning, with a relative emission of $30 \%$.

Based on these data, it is clear that if the amount of greenhouse gas emission is considered alone, the focal points of this issue would only be limited to the pulp production process - specifically, biomass combustion and lime burning, as seen in 


\section{KRAFT PULP INDUSTRY IN THAILAND}

TABLE VI. Greenhouse gas emissions from eucalyptus forestry and kraft pulp production in Thailand (including emissions from biomass-based $\mathrm{CO}_{2}$ ).

\begin{tabular}{|c|c|c|c|c|c|c|c|}
\hline \multirow[t]{2}{*}{ Activity/source } & \multicolumn{2}{|c|}{$\mathrm{CO}_{2}$ emission } & \multicolumn{2}{|c|}{$\mathrm{CH}_{4}$ emission } & \multicolumn{2}{|c|}{$\mathrm{N}_{2} \mathrm{O}$ emission } & \multirow{2}{*}{$\begin{array}{l}\text { Total } \\
\text { Ton } \\
\mathrm{CO}_{2} \text {-eq/ } \\
\text { year }\end{array}$} \\
\hline & $\begin{array}{l}\text { Ton/ } \\
\text { year }\end{array}$ & $\begin{array}{l}\text { Ton } \\
\mathrm{CO}_{2} \text {-eq/ } \\
\text { year }\end{array}$ & $\begin{array}{l}\text { Ton/ } \\
\text { year }\end{array}$ & $\begin{array}{l}\text { Ton } \\
\mathrm{CO}_{2} \text {-eq/ } \\
\text { year }\end{array}$ & $\begin{array}{l}\text { Ton/ } \\
\text { year }\end{array}$ & $\begin{array}{l}\text { Ton } \\
\mathrm{CO}_{2} \text {-eq/ } \\
\text { year }\end{array}$ & \\
\hline Eucalyptus plantation & $-578,451$ & $-578,451$ & - & - & - & - & - \\
\hline \multicolumn{8}{|l|}{ Fertilizer use } \\
\hline Eucalyptus breeding & 0 & 0 & 0 & 0 & 0.1 & 23 & 23 \\
\hline Eucalyptus plantation & 0 & 0 & 0 & 0 & 32 & 9802 & 9802 \\
\hline \multicolumn{8}{|l|}{ Diesel use } \\
\hline Eucalyptus harvest & 2190 & 2190 & 5 & 101 & 0.01 & 4 & 2295 \\
\hline Eucalyptus transportation & 6487 & 6487 & 0.4 & 9 & 0.2 & 63 & 6559 \\
\hline Biomass combustion $^{a}$ & $1,898,424$ & $1,898,424$ & 518 & 10,873 & 69 & 21,400 & $1,930,6$ \\
\hline \multicolumn{8}{|l|}{ Chemical recovery unit } \\
\hline Recovery boiler ${ }^{\mathrm{a}}$ & 3672 & 3672 & 0 & 0 & 0 & 0 & 3672 \\
\hline Lime combustion $^{\mathrm{a}}$ & 867,186 & 867,186 & 0 & 0 & 0 & 0 & 867,186 \\
\hline Bunker oil use & 70,924 & 70,924 & 2 & 38 & 0.5 & 170 & 71,133 \\
\hline Wastewater treatment unit & 6060 & 6060 & 66 & 1389 & 4 & 1385 & 8833 \\
\hline Total & $2,854,943^{\mathrm{b}}$ & $2,854,943$ & 591 & 12,409 & 106 & 32,848 & $2,900,309$ \\
\hline
\end{tabular}

${ }^{\text {a }}$ Sources of biomass-based $\mathrm{CO}_{2}$.

${ }^{\mathrm{b}}$ Total $\mathrm{CO}_{2}$ emission is not subtracted by $\mathrm{CO}_{2}$ from sequestration.

Figure 4(I). However, if one analyzes further to the source of emission, it is clear that these two activities become much less significant. The reason for this is that the emissions of $\mathrm{CO}_{2}$ from biomass combustion can normally be excluded from greenhouse gas inventories since the carbon is derived from trees, in this case, eucalyptus (IPCC, 1997; EPA, 2000). $\mathrm{CO}_{2}$ emission from lime kiln is also not taken into account in most inventories because of the origin of the carbon contained in the calcium carbonate. In the kraft pulping and chemical recovery process, biomass carbon residing in the non-fibrous portions of wood is dissolved and either emitted as $\mathrm{CO}_{2}$ from the recovery furnace or captured in sodium carbonate. In the process of converting the sodium carbonate into new pulping chemicals (sodium hydroxide), this biomass carbon (in the form of the carbonate ion) is transferred to calcium carbonate (Miner and Upton, 2002). As a result, when the emission of $\mathrm{CO}_{2}$ from biomass combustions and lime burning are excluded, the major contributor to greenhouse gases becomes bunker oil use [Figure 4(II)], with the amount of total emission reduced to a mere $0.13 \mathrm{Mton} \mathrm{CO}_{2}$-eq/year.

Figure 4(II) reveals that although the total contribution from forestry becomes more evident through emissions from fertilizer use and eucalyptus transportation, its proportion is still very minor comparing to that of the kraft pulp production. Upon taking into account further the sequestration of $\mathrm{CO}_{2}$ by eucalyptus plantations (Eqs. 3 and 4), which is calculated to be approximately $0.6 \mathrm{Mton} \mathrm{CO}_{2}$-eq/year, this subsystem can be considered to be a minor contributor to the global warming problem. However, the result of $\mathrm{CO}_{2}$ sequestration by eucalyptus is an underestimation because it is calculated from the sequestration of eucalyptus growth only during the fourth year, which is the year that eucalyptus is normally harvested to 
W. JAWJIT ET AL.

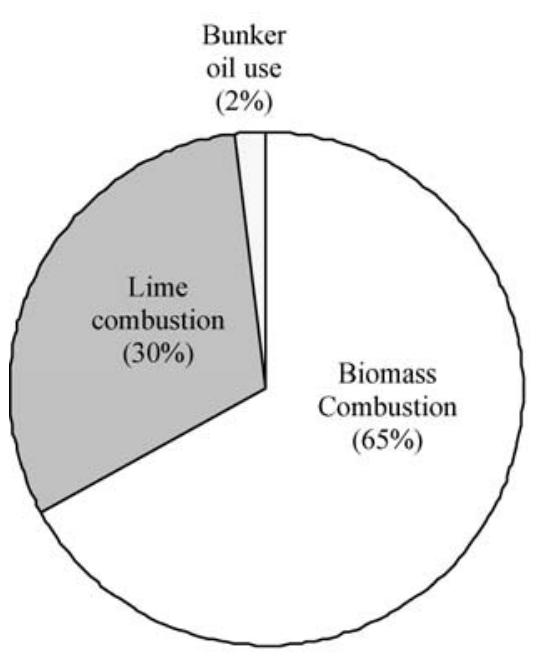

(I)

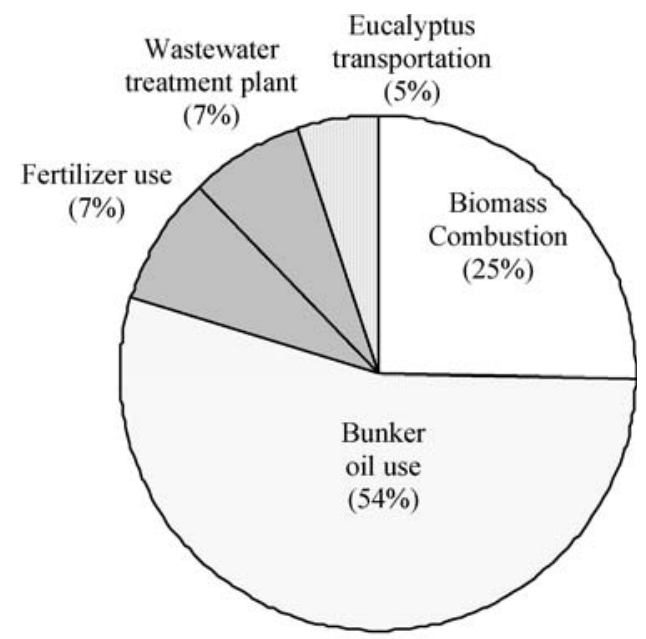

(II)

Figure 4. Relative contribution by different activities/sources to total greenhouse gas emissions from eucalyptus forestry and kraft pulp production in Thailand including(I) and excluding (II) the emission of biomass-based $\mathrm{CO}_{2}$.

produce the pulp. As a first rough estimate of the total sequestration, one may multiply the calculated $0.6 \mathrm{Mton} / \mathrm{year}$ by a factor of four, which will account for the sequestration in the first 3 years of rotation.

\subsection{Acidifying Gases Emission}

The total annual acidifying emissions from $\mathrm{SO}_{2}$ and $\mathrm{NO}_{x}$ were calculated to be 3.6 kton $\mathrm{SO}_{2}$-equivalents (Table VII). When we considered the result in terms of actual and $\mathrm{SO}_{2}$-equivalents, we found that emission of $\mathrm{SO}_{2}$ is larger than that of $\mathrm{NO}_{x}$. The chemical recovery unit was found to be the major contributor to $\mathrm{SO}_{2}$ emission due to the use of $\mathrm{Na}_{2} \mathrm{SO}_{4}$ in the chemical make-up process and the use of bunker oil in the lime kiln. The emission of $\mathrm{NO}_{x}$ comes mainly from combustion in the biomass boiler and recovery boiler and from bunker oil in the lime kiln.

When the contributor of total acidifying emission was considered, we found that the chemical recovery unit contributes the largest proportion $(64 \%$ from recovery boiler, smelt tank, lime combustion and bunker oil use) to the total emissions (Figure 5). The next highest contributor comes from biomass combustion resulting in $\mathrm{NO}_{x}$ emissions, with a relative emission of $34 \%$. The eucalyptus forestry subsystem exhibits only a very small contribution $(3 \%)$ since there is a small $\mathrm{NO}_{x}$ emission from diesel and fertilizer use.

\subsection{Eutrophying Agent Emission}

About 2 kton $\mathrm{PO}_{4}$-equivalents of eutrophying agents was found to be discharged annually, as shown in Table VIII. Among the six pollutants of eutrophying 


\section{KRAFT PULP INDUSTRY IN THAILAND}

TABLE VII. Acidifying emissions from eucalyptus forestry and kraft pulp production in Thailand.

\begin{tabular}{|c|c|c|c|c|c|c|}
\hline \multirow[t]{2}{*}{ Activity/source } & \multicolumn{2}{|c|}{$\mathrm{SO}_{2}$ emission } & \multicolumn{2}{|c|}{$\mathrm{NO}_{x}$ emission } & \multicolumn{2}{|l|}{ Total } \\
\hline & $\begin{array}{l}\text { Ton/ } \\
\text { year }\end{array}$ & $\begin{array}{l}\mathrm{Ton} \\
\mathrm{SO}_{2} \text {-eq/ } \\
\text { year }\end{array}$ & $\begin{array}{l}\text { Ton/ } \\
\text { year }\end{array}$ & $\begin{array}{l}\text { Ton } \\
\mathrm{SO}_{2} \text {-eq/ } \\
\text { year }\end{array}$ & $\begin{array}{l}\text { Ton } \\
\mathrm{SO}_{2} \text {-eq/ } \\
\text { year }\end{array}$ & Percentage \\
\hline \multicolumn{7}{|l|}{ Fertilizer use } \\
\hline Eucalyptus breeding & 0 & 0 & 0.06 & 0.04 & 0.04 & $<<1$ \\
\hline Eucalyptus plantation & 0 & 0 & 26 & 18 & 18 & $<1$ \\
\hline \multicolumn{7}{|l|}{ Diesel use } \\
\hline Eucalyptus harvest & 0 & 0 & 35 & 25 & 25 & 1 \\
\hline Eucalyptus transportation & 41 & 41 & 61 & 43 & 84 & 2 \\
\hline Biomass combustion & 0 & 0 & 1,726 & 1,225 & 1,225 & 34 \\
\hline \multicolumn{7}{|l|}{ Chemical recovery unit } \\
\hline Recovery boiler & 122 & 122 & 630 & 448 & 570 & 16 \\
\hline Smelt tank & 18 & 18 & 6 & 4 & 23 & 1 \\
\hline Lime combustion & 337 & 337 & 202 & 143 & 480 & 13 \\
\hline Bunker oil use & 1,094 & 1,094 & 183 & 130 & 1,224 & 34 \\
\hline Total & 1,612 & 1,612 & 2,870 & 2,037 & 3,650 & 100 \\
\hline
\end{tabular}

agents $-\mathrm{NO}_{3}, \mathrm{NO}_{x}, \mathrm{PO}_{4}$ from fertilizer use; $\mathrm{N}$ and $\mathrm{COD}$ from the pulp production unit; $\mathrm{P}$ from the wastewater treatment unit - we found that COD was proportionally the most abundant pollutant discharged (12,240 ton/year in total). However, when we considered these eutrophying agents as nutrient potential (NP) substances in terms of $\mathrm{PO}_{4}$-equivalents, $\mathrm{P}$ in the effluent was the most abundant (1,573 ton $\mathrm{PO}_{4}$-eq/year), followed by $\mathrm{COD}$ from the pulp production unit (269 ton $\mathrm{PO}_{4}$-eq/year) and $\mathrm{PO}_{4}$ from fertilizer use in eucalyptus plantations (211 ton $\mathrm{PO}_{4}$-eq/year). The increase in $\mathrm{P}$ following biological aerobic treatment derives from the application of fertilizer for stimulating microbial activity. Although the eucalyptus forestry subsystem plays a more significant role in the eutrophication problem than global warming and acidification, the main contributor to this problem is still pollutants (COD and $\mathrm{P}$ ) from the kraft pulp production subsystem, which accounts for $88 \%$ of the total emission (Figure 6).

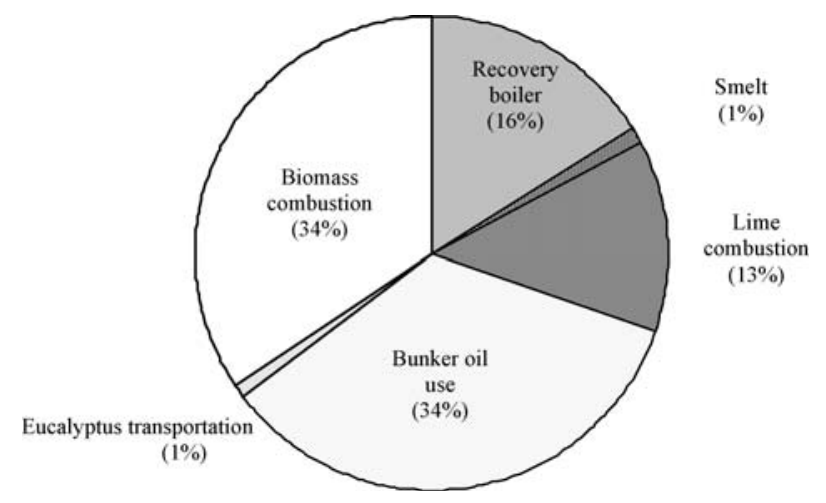

Figure 5. Relative contribution of different activities/sources to total acidifying emissions from eucalyptus forestry and kraft pulp production in Thailand. 


\section{W. JAWJIT ET AL.}

TABLE VIII. Eutrophying emissions from eucalyptus forestry and Kraft pulp production in Thailand.

\begin{tabular}{lccc}
\hline Activity/source & \multicolumn{2}{l}{ Eutrophying emission } & Total (\%) \\
\cline { 2 - 3 } & Ton/year & Ton $\mathrm{PO}_{4}$-eq/year & \\
\hline Fertilizer use & & & \\
$\quad$ Eucalyptus breeding $\left(\mathrm{NO}_{x}\right)$ & 0.06 & 0.01 & $<<1$ \\
Eucalyptus breeding $\left(\mathrm{NO}_{3}\right)$ & 0.9 & 0.1 & $<<1$ \\
Eucalyptus breeding $\left(\mathrm{PO}_{4}\right)$ & 0.2 & 0.2 & $<<1$ \\
Eucalyptus plantation $\left(\mathrm{NO}_{x}\right)$ & 26 & 3 & 2 \\
Eucalyptus plantation $\left(\mathrm{NO}_{3}\right)$ & 369 & 37 & 10 \\
Eucalyptus plantation $\left(\mathrm{PO}_{4}\right)$ & 211 & 211 & 2 \\
Pulp production unit & & & 4 \\
Wood handling (COD) & 1,836 & 80 & 7 \\
Pulp washing (COD) & 3,672 & 148 & 2 \\
Pulp bleaching (COD) & 6,732 & 49 & 73 \\
Pulp bleaching (N) & 116 & & 100 \\
Wastewater treatment unit & & 1,573 & \\
$\quad$ Phosphorus (P) & 514 & 2,142 & \\
Total & & & \\
\hline
\end{tabular}

It should be noted that the amount of fertilizer use in eucalyptus plantations was estimated from the recommendation of the eucalyptus producer company to their contract farmers. In practice, however, the farmers are likely to apply fertilizer at levels lower than those suggested by the producer company. Consequently, the results of nutrient emission from eucalyptus plantations, as presented here, may be overestimated.

\subsection{Tropospheric Ozone Precursor Emission}

We determined the total emissions of tropospheric ozone precursor compounds to be about $1.7 \mathrm{kton}$ ethylene-eq/year (Table IX). Among the four main components of tropospheric ozone precursors - NMVOC, $\mathrm{CO}, \mathrm{CH}_{4}$ and $\mathrm{NO}_{x}-$ we found that $\mathrm{CO}$ accounts for almost all of the emissions in terms of both actual and $\mathrm{C}_{2} \mathrm{H}_{2}$-equivalent amounts. There are only two main important sources with respect to contributors to the smog problem: biomass combustion and the chemical recovery unit. Biomass combustion in the energy production unit ranks the first, with a share of almost $80 \%$. The second contributor belongs to the chemical recovery unit, with the relative emission share of $14 \%$ (Figure 7). Similar to the emission of acidifying gases, the eucalyptus forestry subsystem emits a very small proportion $(<1 \%)$ of the total tropospheric ozone precursor compounds and can, in fact, be considered to be negligible with respect to this environmental problem.

\subsection{Human Toxicity}

The total emissions of human toxicity compounds are about $6.9 \mathrm{kton} \mathrm{C}_{6} \mathrm{H}_{4} \mathrm{Cl}_{2}$-eq/ year (Table X). Among the four pollutants considered - TRS, AOX, $\mathrm{SO}_{2}, \mathrm{NO}_{x}$ and particulates - we found that AOX emission from pulp bleaching is the highest 


\section{KRAFT PULP INDUSTRY IN THAILAND}

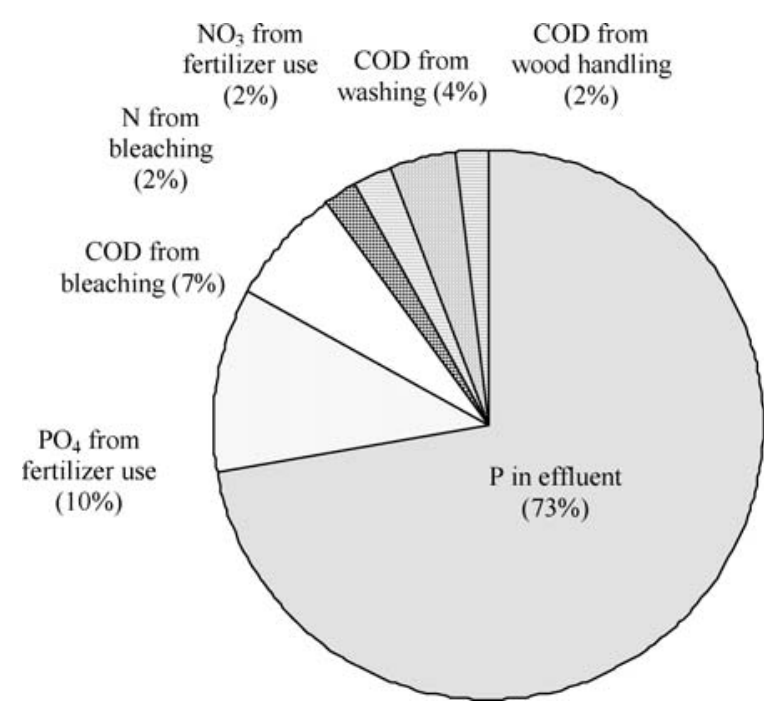

Figure 6. Relative contribution of different activities/sources to total eutrophying emissions from eucalyptus forestry and Kraft pulp production in Thailand.

(1.84 kton/year). Nevertheless, when we considered these compounds as human toxicity substances in terms of $\mathrm{C}_{6} \mathrm{H}_{4} \mathrm{Cl}_{2}$-equivalents, $\mathrm{NO}_{x}$ emissions from biomass combustion exhibit the highest amount ( $2.07 \mathrm{kton} \mathrm{C}_{6} \mathrm{H}_{4} \mathrm{Cl}_{2}$-eq/year), followed by AOX from pulp bleaching in the pulp production unit and $\mathrm{NO}_{x}$ from the chemical recovery unit. Odorous TRS is emitted as a result of pulp cooking and the chemical recovery unit at amounts of 1530 and 30 ton TRS and 337 and 7 ton $\mathrm{C}_{6} \mathrm{H}_{4} \mathrm{Cl}_{2}$ equivalents, respectively. For the eucalyptus forestry subsystem, emissions of human toxicity compounds were found as a result of diesel use and fertilizer use, but these only account for about $1 \%$ of the total emissions (Figure 8).

\subsection{The Production of Waste}

The results of solid waste generation from kraft pulp production were derived directly from mill visits and literature searches. We found that most of the raw material residues (organic residues, bark and wood) are used as fuel in boilers to produce energy. These organic wastes amount to about 283,240 ton/year. Sludge from the wastewater treatment plant, which is also sent to the boilers following a dewatering process, amounts to 9125 ton/year. Solid wastes that cannot be recycled into any of the processing units include solid waste from the recovery unit, such as lime mud, dregs and grits. The final disposal of these wastes is by means of landfill. The amount of lime mud which needs to be landfilled is 60,955 ton/year, whereas amount of dredge, ash, grit and scale that is generated from the energy generation unit, chemical recovery unit and other combustion sources is 93,075 ton/year (DIW, 1999) (Table XI). 
W. JAWJIT ET AL.

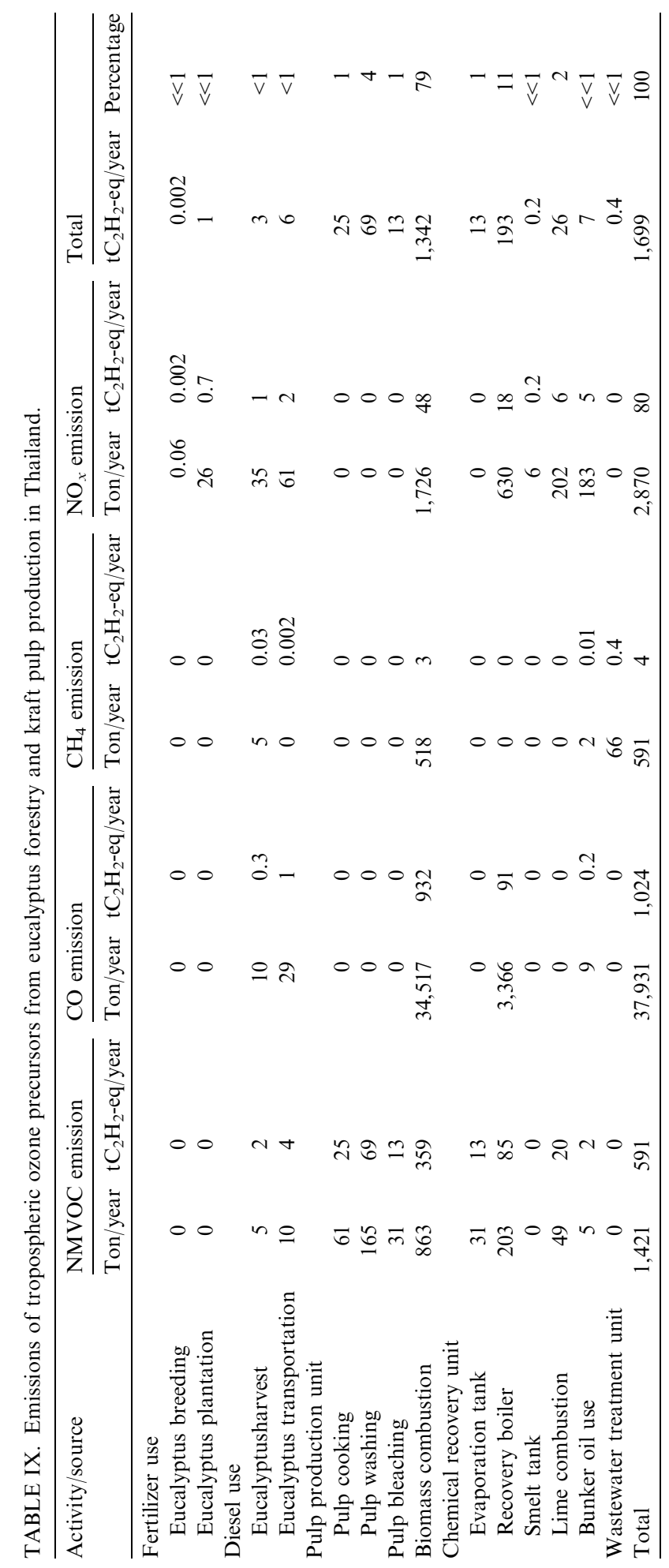




\section{KRAFT PULP INDUSTRY IN THAILAND}

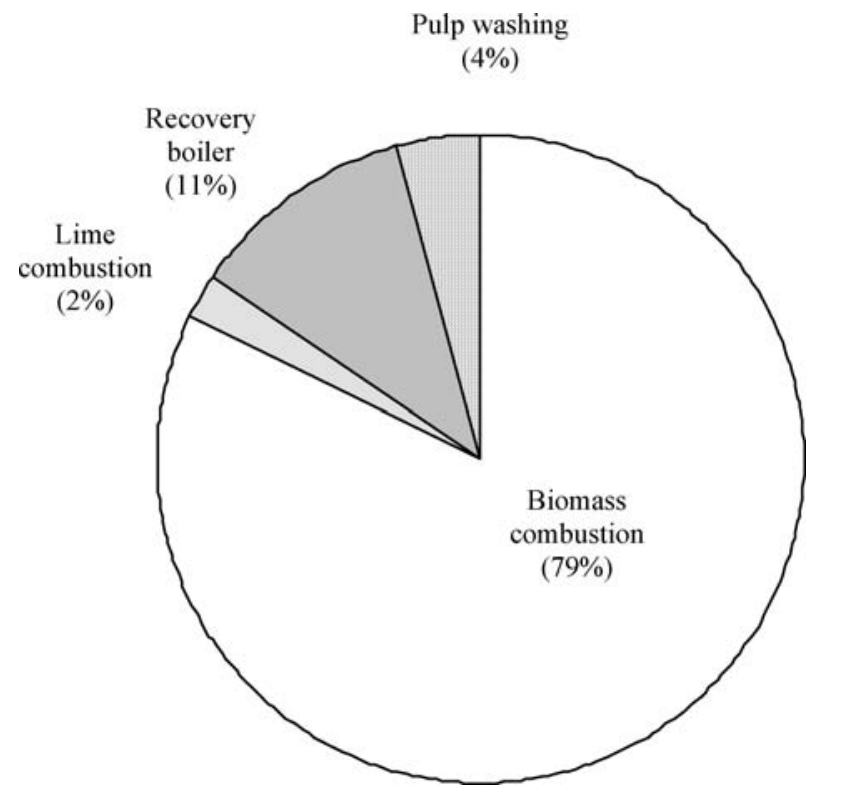

Figure 7. Relative contribution (ethylene equivalent) of different activities/sources to the total emission of tropospheric ozone precursors from kraft pulp production in Thailand.

\section{Conclusion}

The sources of environmental pressure intrinsic in the kraft pulp industry in Thailand have been identified for six environmental problems: global warming, acidification, eutrophication, smog, human toxicity and the production of waste. To this end, we distinguished between two subsystems within the kraft pulp industry: eucalyptus forestry and kraft pulp production. We found that emissions from the eucalyptus forestry subsystem are small compared to those from the kraft pulp production. The environmental pressure from forestry can thus be considered to be a minor contributor to all environmental problems falling within the framework of the kraft pulp industry in Thailand.

With respect to the kraft pulp production subsystem, we found that there are four important sources of environmental pressure, namely, the energy generation unit, chemical recovery units, pulp production units and wastewater treatment unit. The combustion of fuels, both biomass and bunker oil, is the most important source of pollution related to greenhouse gases, smog precursors and human toxicity compounds, with $\mathrm{CO}_{2}, \mathrm{CO}$ and $\mathrm{NO}_{x}$ being the most important pollutants, respectively. The chemical recovery unit is the main source of $\mathrm{SO}_{2}$ and inorganic solid waste related to the problem of acidification and the production of waste, respectively. Bleaching in the pulp production unit is the major source of AOX causing toxicity problems, whereas the aerobic wastewater treatment unit is the most important cause of eutrophication, with the emission of $\mathrm{P}$ as the prime cause. For odor 
W. JAWJIT ET AL.

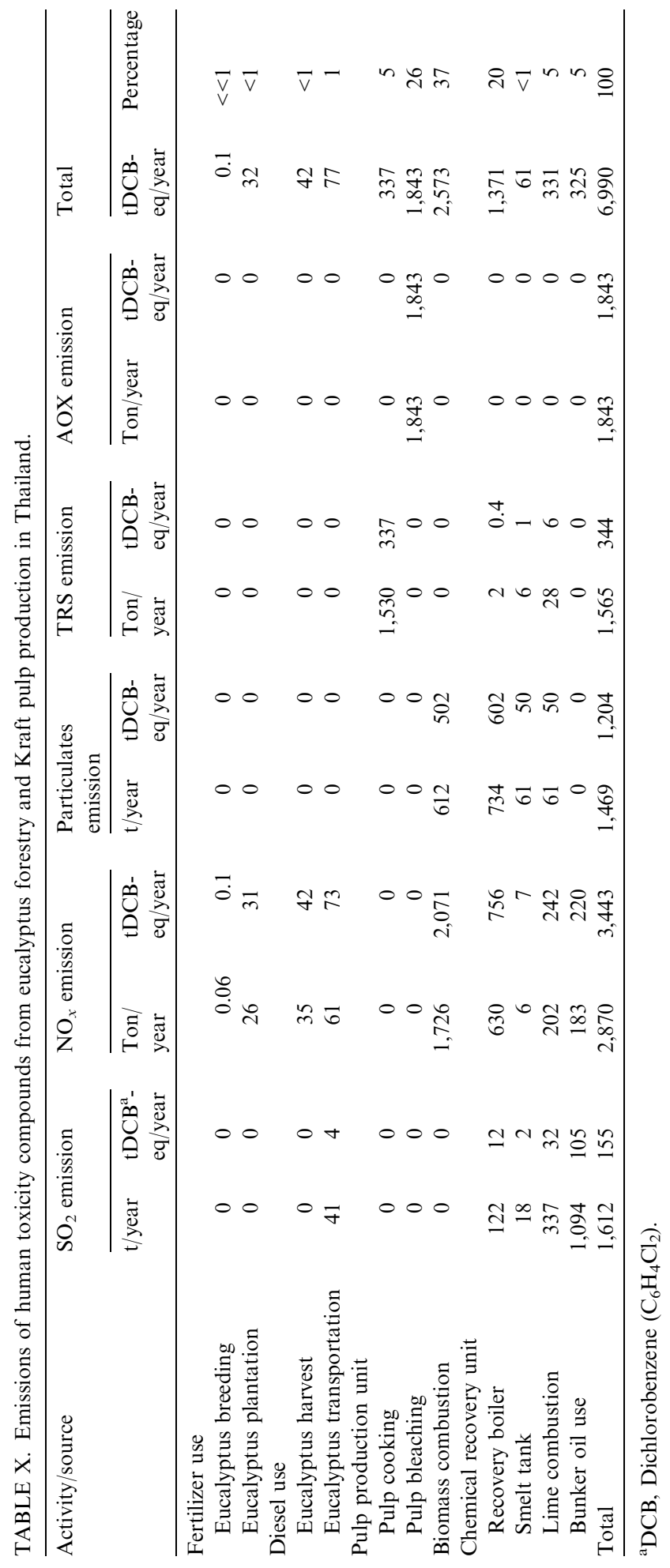




\section{KRAFT PULP INDUSTRY IN THAILAND}

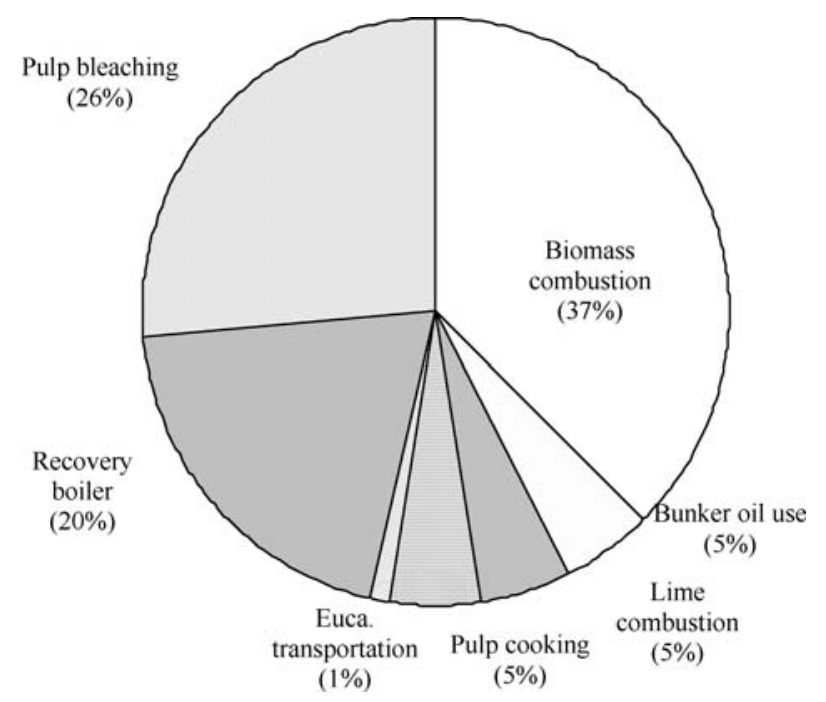

Figure 8. Relative contribution (ethylene equivalent) of different activities/sources to total emission of human toxicity compounds from kraft pulp production in Thailand.

TABLE XI. Solid waste generation from kraft pulp production in Thailand.

\begin{tabular}{llll}
\hline Pollutant & Activity & Source & Emission (ton/year) \\
\hline $\begin{array}{l}\text { Organic waste } \\
\text { Raw materials } \\
\text { residue } \\
\text { Sludge }\end{array}$ & Debarking & Raw material preparation & 283,240 \\
$\begin{array}{l}\text { Inorganic waste } \\
\text { Lime mud residue } \\
\text { Dregs, grit and ashes }\end{array}$ & $\begin{array}{l}\text { Wastewater } \\
\text { treatment }\end{array}$ & Wastewater treatment plant & 9,125 \\
& Fuel combustion & $\begin{array}{l}\text { Chemical recovery unit } \\
\text { Chemical recovery unit } \\
\text { and energy generation unit }\end{array}$ & \\
\hline
\end{tabular}

problems, pulp cooking and the chemical recovery unit were found to be the important sources of TRS emission.

In additions to the major emissions mentioned above, other emissions, which contribute to at least $85 \%$ of the total emissions in each environmental theme, should also be taken into account when identifying options to reduce the environmental impact of the kraft pulp industry in Thailand (Table XII). In conclusion, the sources of emissions which we have taken into account are: (1) the energy generation unit through biomass combustion with emissions of $\mathrm{CH}_{4}, \mathrm{~N}_{2} \mathrm{O}, \mathrm{NO}_{x}, \mathrm{CO}$, VOC and particulates; (2) bunker oil use in lime burning with emissions of $\mathrm{CO}_{2}$ and $\mathrm{SO}_{2}$; (3) lime combustion with emissions of $\mathrm{SO}_{2}, \mathrm{NO}_{x}, \mathrm{VOC}$; (4) the pulp production unit with emissions of AOX, COD and TRS; (5) the wastewater treatment unit with emissions of $\mathrm{P}$; (6) eucalyptus plantation through fertilizer use with emissions of $\mathrm{N}_{2} \mathrm{O}$ and $\mathrm{PO}_{4}{ }^{3-}$. 


\section{W. JAWJIT ET AL.}

TABLE XII. The emission of pollutants that are responsible for $85 \%$ or more of the total contribution to global warming, acidification, eutrophication, smog and human toxicity.

\begin{tabular}{|c|c|c|c|}
\hline Environmental theme & Pollutant & Source & $\begin{array}{l}\text { Contribution } \\
\text { total emission (\%) }\end{array}$ \\
\hline Global warming & $\mathrm{CO}_{2}$ & Biomass combustion & 65 \\
\hline (including biomass-based $\mathrm{CO}_{2}$ ) & $\mathrm{CO}_{2}$ & Lime combustion & 30 \\
\hline Global warming & $\mathrm{CO}_{2}$ & Bunker oil use ${ }^{\mathrm{a}}$ & 54 \\
\hline \multirow[t]{3}{*}{ (excluding biomass-based $\mathrm{CO}_{2}$ ) } & $\mathrm{N}_{2} \mathrm{O}$ & Biomass combustion & 16 \\
\hline & $\mathrm{CH}_{4}$ & Biomass combustion & 8 \\
\hline & $\mathrm{N}_{2} \mathrm{O}$ & $\begin{array}{l}\text { Fertilizer use in } \\
\text { eucalyptus plantation }\end{array}$ & 7 \\
\hline \multirow[t]{5}{*}{ Acidification } & $\mathrm{NO}_{x}$ & Biomass combustion & 34 \\
\hline & $\mathrm{SO}_{2}$ & Bunker oil use & 30 \\
\hline & $\mathrm{NO}_{x}$ & Recovery boiler & 12 \\
\hline & $\mathrm{SO}_{2}$ & Lime combustion & 9 \\
\hline & $\mathrm{NO}_{x}$ & Lime combustion & 4 \\
\hline \multirow[t]{3}{*}{ Eutrophication } & $\mathrm{P}$ & Wastewater treatment unit & 73 \\
\hline & $\mathrm{PO}_{4}{ }^{3-}$ & $\begin{array}{l}\text { Fertilizer use in } \\
\text { eucalyptus plantation }\end{array}$ & 10 \\
\hline & COD & Wastewater treatment unit & 7 \\
\hline \multirow[t]{4}{*}{ Smog } & $\mathrm{CO}$ & Biomass combustion & 55 \\
\hline & NMVOC & Biomass combustion & 21 \\
\hline & $\mathrm{CO}$ & Recovery boiler & 5 \\
\hline & NMVOC & Recovery boiler & 5 \\
\hline \multirow[t]{6}{*}{ Human toxicity } & $\mathrm{NO}_{x}$ & Biomass combustion & 30 \\
\hline & $\mathrm{AOX}$ & Pulp bleaching & 26 \\
\hline & $\mathrm{NO}_{x}$ & Recovery boiler & 11 \\
\hline & Particulate & Recovery boiler & 9 \\
\hline & Particulate & Biomass combustion & 7 \\
\hline & TRS & Pulp cooking & 5 \\
\hline
\end{tabular}

${ }^{a}$ Bunker oil is used in lime kiln.

\section{Acknowledgements}

We would like to thank Wageningen University, the Netherlands for funding under the AGITS (Agro-Industrial Transformation Towards Sustainability) project. We also thank the National Research Center for Environmental and Hazardous Waste Management (NRC-EHWM) of Chulalongkorn University, Thailand for their kind assistance during the work in Thailand.

\section{References}

Bordado, J.C.M. and Gomes, J.F.P.: 2003, 'Atmospheric emissions of kraft pulp mills', Journal of Cleaner Production 11, 797-801.

CML: 2002, Impact Assessment Spreadsheet Version 2.6, The Netherlands, Center of Environmental Science, Leiden University.

CORINAIR: 2000, Atmospheric Emission Inventory Guidebook, 2nd edn ed. Copenhagen, Denmark, The Core Inventory of Air Emission in Europe, European Environment Agency.

De Feyter, S.: 1995, 'Handling of the carbon balance of forest in LCA', In A. Fruhwald and B. Solberg (eds), Life Cycle Analysis - A Challenge for Forestry and Forest Industry, Hamburg, Germany, 


\section{KRAFT PULP INDUSTRY IN THAILAND}

Proceedings of the International Workshop, The European Forest Institute and the Federal Research Center for Forestry and Forest products.

DIW: 1999, Technical Guideline for Environmental Management for Pulp and Paper in Thailand, Bangkok, Thailand, Department of Industrial Work, Bureau of Environmental Technology, Ministry of Industry.

EC, 2001, Integrated Pollution Prevention and Control (IPPC): Reference document of the Best Available Techniques in the Pulp and Paper Industry. European Commission, Luxembourg.

ERIC and TPPIA: 2002, Application of the Production Performance Indicators in Accordance with Global Reporting Initiative (GRI) to Thai Pulp and Paper Industries, Bangkok, Thailand, Thai Pulp and Paper Industries Association (Thai edition).

EPA: 1993, Handbook on Pollution Prevention Opportunities for Bleached Kraft Pulp and Paper Mills, Washington, D.C., US Environmental Protection Agency.

EPA: 2000, Inventory of U.S. Greenhouse Gas Emissions and Sinks: 1990-1998, Washington D.C., United

States Environmental Protection Agency, Report No. EPA 236-R-00-001.

Goedkoop, M.: 2000, The Eco-indicator 99, Final Report, Amersfoort, Pre-consultants.

Hoamuangkaew, W., Prasomsit, P. and Suntornhow, P.: 1999, Inventory of Private Eucalyptus Plantation in Thailand in 1997, Bangkok, Thailand, Kasetsart University (Thai edition).

Heijungs, R.: 1992, Environmental Life Cycle Assessment of products, Guidelines and backgrounds, Center of Environmental Science (CML), Leiden, The Netherlands, Leiden University.

Houghton, J.T.: 1994, Radiative Forcing of Climate Change and An Evaluation of the IPCC Emission Scenarios. Intergovernmental Panel on Climate Change (IPCC), Cambridge, Cambridge, Cambridge University Press.

IPCC: 1997, Greenhouse Gas Inventory Reference Manual, IPCC Guidelines for National Greenhouse Gas Inventories Volume 3, Bracknell, Intergovernmental Panel on Climate Change.

Maclaren, J.P.: 1996, 'Plantation forestry: its role as a carbon sink', In W.J. Brown, G.I. Dearman and M.R. Manning (eds), Greenhouse: Coping with Climate Change, Australia, CSIRO Publishing, pp. 417436.

Miner, R. and Upton, B.: 2002, 'Methods for estimating greenhouse gas emissions from lime kilns at kraft pulp mills', Energy 27(8), 729-738.

Ongmongkolkul, A. and Nielsen, P.: 2001, Life Cycle Assessment of Paperboard Packaging produced in Thailand, School of Environment, Resource and Development, Thailand, Asian Institute of Technology (AIT).

PCD: 1996, Database of Air and Noise Pollution Sources in Thailand year 1994: A Final Report, Thailand, Pollution Control Department, Ministry of Science, Technology and Environment (Thai edition).

Pluimers, J.C.: 2001, An Environmental Systems Analysis of Greenhouse Horticulture in the Netherlands: the Tomato Case, PhD. thesis, Wageningen, The Netherlands, Wageningen University.

Poethai, M.: 1997, Handbook of Eucalyptus Plantation, 4th ed. Bangkok, Thailand, M.P. Reforestation Group (Thai edition).

Poyry, J.: 1992, Technical and Economical Evaluation of Water Pollution Control in Pulp Mill, Jaakko Poyry Consulting, Helsinki.

UNEP: 1996, Environmental Management in the Pulp and Paper Industry, Stockholm, Sweden, United Nations Environment Programme: Industry and Environment.

Schwaiger, H. and Zimmer, B.: 1995, 'A comparison of fuel consumption and greenhouse gas emissions from forest operations in Europe', In B. Solberg and L. Roihuvo (eds), Environmental Impacts of Forestry and Forest Industry, Joensuu, Finland, Proceeding of the International Seminar organised by the Finnish-French Society of Science and Technology and the European Forest Institute.

TEI, 1997, Thailand's National Greenhouse Gas Inventory 1990. Thailand Environment Institute, submitted to Office of Environmental Policy and Planning, Ministry of Science, Technology and Environment Bangkok, Thailand.

TEI, 1999, Industrial Environmental Performance Indicators, the Third Progress Report, Submitted to Pollution Control Department, Ministry of Science, Technology and Environment Bangkok, Thailand (Thai edition). 